\title{
Theodor Bilharz and a life trip to Egypt
}

\author{
Editorial Nadia A El-Dib
}

Department of Medical Parasitology, Faculty of Medicine, Cairo University, Cairo, Egypt

Theodore Bilharz, the German professor born in Sigmaringen in 1825, is one of the eminent professors in the history of Parasitology and Tropical Medicine. He came to Egypt as an assistant of Professor Griesinger in the year 1850, and was fascinated with the country, to the degree that he studied Arabic and hieroglyphic languages in order to understand Egypt and the Egyptians. He was assigned to work in Kasr Al Ainy hospital in Cairo where he served the patients and lectured the medical students. During his work, he detected the blood fluke Distomum haematobium (that was later called Schistosoma), the causative agent of hematuria and severe diseases among the Egyptians since ancient time. This discovery is considered a very important advancement in the recognition of the disease and its control. Bilharz died in Egypt and was buried in Cairo. The Ministry of Health in Egypt honored him by establishing the Institute of Theodor Bilharz, for schistosomiasis research.

Keywords: bilharzia, Distomum haematobium, H. heterophyes, H. nana, S. haematobium, Theodor Bilharz.

Received: 2 March, 2019, Accepted: 22 March, 2019.

Corresponding Author: Tel.: 00201001171606, E-mail: naeldib@hotmail.com

Print ISSN: 1687-7942, Online ISSN: 2090-2646, Vol. 12, No. 1, April, 2019.

\section{The early life of Theodor Bilharz}

The year 1851 is considered an important date in the history of Tropical Medicine and Parasitology. In this particular year, the young German physician Theodor Maximilian Bilharz (Figure 1) managed to reveal the mystery of hematuria known since antiquity in Egypt. This discovery is one of the major events in the history of medicine. Theodor Bilharz was born on $23^{\text {rd }}$ of March, 1825 in the town of Sigmaringen, in the Dukedum of Hohenollern on the Danube in Germany ${ }^{[1]}$. He grew up in a typical Biedermeier environment. His father, Josef Antony Bilharz (1788-1877), was a councilor of the exchequer, the advisor to Prince Karl Anton of Hohenzollern-Sigmaringen (1811-1885). His mother Elsa Fehr was born in Switzerland to a well-known family, and got married to Mr. Josef Bilharz in 1824 . Theodor was the first of nine children in his family. He liked his youngest brother Alfons and used to spend time and share activities with him. He loved nature, collected samples of rocks, plants and butterflies, which he examined and described carefully with great precision. He had a great interest in literature and was even talented in writing poems; one of them is: "Die Trane des Seraphs" or "The travels of the Seraphs", but he didn't know that he might be one of these seraphs ${ }^{[1]}$.

\section{Studies of Theodor Bilharz}

Theodor Bilharz studied in the secondary school of Simaringen and finished the Fürstlich Sigmaringer Gymnasium with good marks. Later, he studied philosophy for two years at the Albert-LudwigsUniversität in Freiburg im Breisgau, where his studies included mathematics, physics, chemistry, mineralogy, botany, geology, archaeology, antique art, history, ethics and psychology ${ }^{[2]}$. He added to this long list of studies, English and French languages. He was

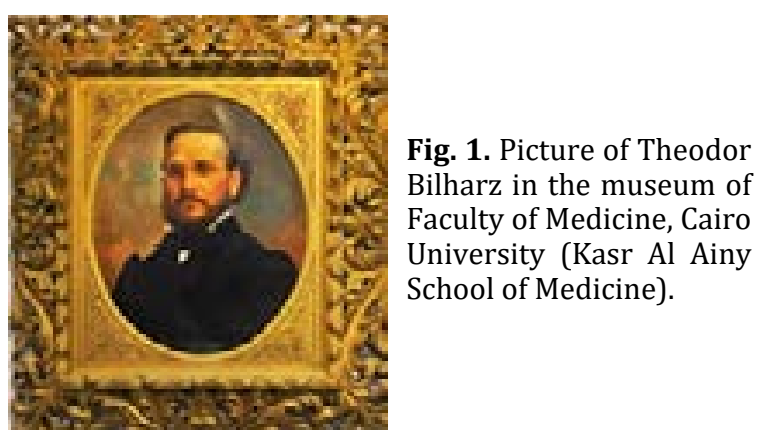

well known by his professors for his excellence and enthusiasm $^{[3]}$. Young Bilharz was deeply influenced by some of his teachers; one of them was Friedrich Arnold (1803-1890) who helped him to develop an interest in medical research, especially comparative anatomy. Bilharz began his studies in medicine at the University of Tübingen from 1845, under the supervision of Professor Friedrich Arnold, who accepted the chair of anatomy and physiology at the same university in the same year. The lectures and courses of Professor Arnold, his excellent presentations and his teaching talents were unique and were extremely admired by his student Bilharz, who wrote the following comments "In medicine, everything depends on the teacher - the method, the mental band by which he is able to link scarce and ambiguous facts"[1]. Later in 1847, Bilharz won the medical faculty's prize competition for his paper on the blood of invertebrates ${ }^{[2,4]}$. Bilharz's interest in medicine went side by side with other interests, and he used to introduce himself as: "My name is Theodor Bilharz. I come from Sigmaringen. I study Medicine, but a lot of other things are interesting for me; Botanik, Osteologie, Zoologie, Mineralogie, Geologie and last but not least Meteorologie. Neither at the beginning nor in 
the course of my studies, it is the real medicine, which attracts me. It is the natural science, among them, the morphology and physiology of humans and animals that attract" ${ }^{\prime 5]}$. In 1849, he passed the state examination in Sigmaringen and the following year he received his doctorate at Tübingen.

Another teacher who influenced the life and studies of Bilharz at Tübingen was Carl Theodor von Siebold (1804-1884) ${ }^{[2]}$, under whose direction Bilharz returned to Freiburg to study Biology and Helminthology. Theodor received his Doctor diploma without any exams, which was considered as an unusual achievement ${ }^{[1]}$. He started his scientific studies in Helminthology in Germany with von Siebold, who advised him to investigate helminthes in Egypt. At that time the European scientists focused their interest on the life history of tapeworms ${ }^{[1]}$. During this period, young Bilharz was sharing his time between Tübingen and Freiburg, where he studied under the supervision of both Arnold "the great Anatomist" and von Siebold "the great Zoologist". They influenced his learning to such an extent that he followed his teacher Arnold to the University of Tübingen where he became acquainted with the 33-years old German neurologist and psychiatrist Wilhelm Griesinger (1817-1868) ${ }^{[3]}$. His meeting with Griesinger was very important in his career, as together they could make part of medical history, not only in Egypt, but also in the world ${ }^{[6]}$.

After graduation, Bilharz found it difficult financially to pursue his studies and decided to apply to Mexico, where he expected that his research and practice in medicine would be easier. He thought that the route to the professional chair was shorter in South America than it was in Tübingen ${ }^{[6]}$. In the year 1850, Bilharz received an appointment by Georg Ludwig Kobelt (1804-1857) as a provisional prosector ${ }^{[1]}$. Kobelt the German anatomist from Baden was a famous professor of anatomy, who studied Medicine at the University of Heidelberg (1781- 1861) ${ }^{[7]}$. In the same year, Bilharz was invited by his professor Wilhelm Griesinger (Figure 2) to assist him in his new mission as Chief of Health and Supervisor of Kasr Al Ainy School of Medicine in Cairo, Egypt. Griesinger, was requested to occupy the chair of professorship of Pathology in Kiel University, instead of which he accepted to serve in Egypt. When von Siebold knew about his student's mission, he sent to Theodor Bilharz's father saying, "I can't help it to speak out the wish that the stay of your good Theodor may be a credit to him and to science. As far as I had the pleasure to get to know this young man, I won't believe anything else than that a longer stay in wonderful Egypt would be excellently used by your son. God may save his health"[1].

\section{His mission in Egypt}

Bilharz was so pleased to receive this invitation to go to Egypt to the degree that he was unable to sleep during the night. He began his journey on May 25, 1850,

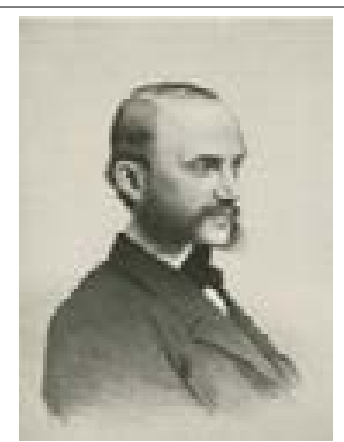

Fig. 2. Professor Griesinger.

from Vienna to join Griesinger's family and the whole group sailed to Alexandria, where they landed on the $18^{\text {th }}$ of June $1850^{[8]}$. When Griesinger asked Bilharz to assist him, he was aware of his qualities having worked with him at Tübingen as a lecturer proving to be knowledgeable, hardworking, and one of the best among his students ${ }^{[3]}$. Once in Cairo, Bilharz and Griesinger stayed together in Azbakia area in a beautiful house, from where they used to go every morning to the school of medicine of Kasr Al Ainy ${ }^{[8]}$. Soon after the arrival of Bilharz to Egypt, he began to give lectures and supervised the military hospital's clinical departments at Kasr Al Ainy Hospital ${ }^{[9]}$. He worked hard to serve science and patients in a sincere collaboration with his Austrian colleagues Reyer and Lautner, the lecturers at Kasr Al Ainy Medical School. His bag was full of scientific medical problems to solve by his old teachers Siebold, Arnold, Erker and others. This medical school where he worked, was established by Clot Bey in 1827 at Abu Zaabal and then was transferred to the old palace of Ahmed Ibn Al Ainy in 1837. It was the biggest and oldest hospital in Africa and the Middle East ${ }^{[10]}$. In the summer of 1850, he wrote to his friend and former teacher Professor Karl Theodor Ernst von Siebold in Breslau "In regard to the helminthes in general, including those in human beings, I believe that Egypt is an extremely favorable country for studying their development" ${ }^{[8]}$.

Later, Bilharz moved to live in a poor area in old Cairo (Misr El-Kadima), with his servant Aly. This was not because of his modesty, but because of his burning desire and determination to study the people of Egypt and their anthropological nature. This sort of determination captured his loyalty, love and intention to study without hesitation. He began studying hieroglyphic language, as shown by his handwriting in his notes (Figure 3) and added to his knowledge, the learning of Arabic language, with which he could find his way among the people of Egypt. Bilharz never allowed the lack of facilities to hinder his work and studies $^{[6]}$.

\section{The Discovery of Distomum haematobium}

One year later, Bilharz reported the following to his professor von Siebold in Germany, in a letter dated 1st May 1851; "After I directed my attention to the liver and its connection, I soon found in the blood of the portal artery a large quantity of a long white helminth; 
Fig. 3. Two pieces of papers with handwriting of Bilharz of hieroglyphic language. looking at it with the naked eye, I took it for a nematode, but soon recognized that it was something new".

A short time later, on 28th August 1851, Bilharz wrote to Siebold again (Figure 4): "I have not yet reported to you on the new phases that my portalartery worm has entered. It has not turned into ... an 'old wives' tale, rather something that I would call even more amazing: a trematode with separate sexes. The worm I described in my last letter was the male. Upon more careful examination ..... of the intestinal veins, I soon found examples of the worm containing a gray thread in the caudal furrow .... The female could easily be pulled out of the furrow of the male and clearly recognized in its inner structure". Shortly, von Siebold summarized these observations of Bilharz into a report that was published in the Zeitsihrift für Wissenschaftliche Zoologie in $1852^{[11]}$. By 1853, Bilharz was able to identify the worms, which he named Distomum haematobium and their eggs in the bladder and the liver of a dead Egyptian soldier and to describe the disease, which remains his enduring scientific legacy ${ }^{[3,12]}$.

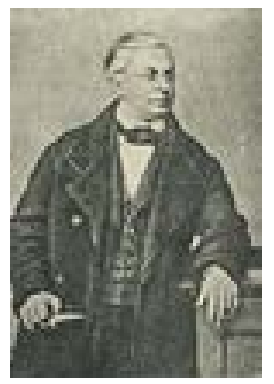

Fig. 4. Professor von Siebold.

When Said Pasha (Figure 5), came to rule Egypt, he assigned the supervision of Kasr Al Ainy School of Medicine to the French physician Clot Bey, who invited a French team to assist him. Griesinger had to leave early in 1852 and Bilharz fell in disfavor. However, Clot Bey accepted him as a professor of Anatomy to keep him away from Medicine and Surgery. Bilharz accepted the new job willingly, and continued in teaching Anatomy ${ }^{[6]}$. Soliman Pasha Elfaransawy (the French General of the Egyptian Army) at the time of Mohamed Ali placed his palace, at the side of the Nile, at the disposal of Bilharz, Reyer and Lautner, where they lived. Bilharz had to replace his professor in serving the Khedive as a private physician. Although he dreamt of escaping from the administrative

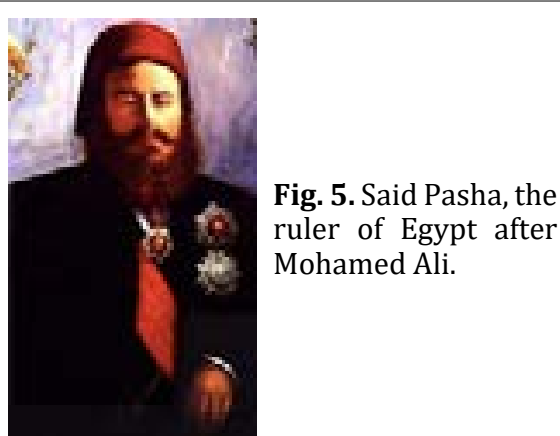

work and go to the Red Sea to study marine biology, he couldn't and stayed in his original job ${ }^{[6]}$.

His brother Alfons (Figure 6), visited him in Egypt, stayed for seven months with him and wrote in the family's chronicles "My brother was residing in one of the smaller Arabian houses in old Cairo, not far from Soliman Pasha's palace, where the Reyer and the Lautner family lived in a wing that was attached for their use. Earlier, my brother had lived in a quite similar house until it was split from the top to the bottom by the earthquake of $1853^{\prime \prime}[1]$.

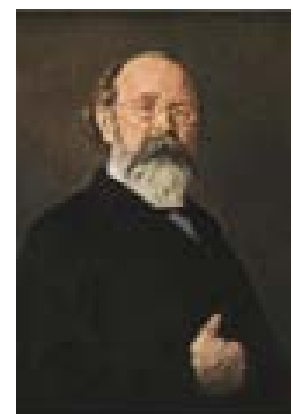

Fig. 6. Alfons Bilharz, Theodor's beloved brother.

Later, in the year 1856, Bilharz reported in the Wiener Medizinische Wonchenschrift on his new discovery Distomum haematobium. He not only described the adult worms, but he also mentioned the eggs and wrote: "in these fine eggs, the various stages of embryonic development can easily be observed". Although he identified different shapes of eggs, he didn't realize that these eggs belong to two different species of worms. After examination of eggs he wrote about the miracidium "the animal swims around in rolling motions"[11,12].

He also linked the newly identified parasite with hematuria, a symptom of a disease known in Egypt since ancient times. Before the year 1800, several scientists just pointed out to the particular prevalence of the disease in Egypt, and Napoleon's army also suffered from hematuria during the short invasion of Egypt. Bilharz was able to identify the important pathological complications in the bladder, ureters and seminal vesicle as well as in the intestine as being related to infection with the newly identified trematode Distomum haematobium. He described this in his letters to von Siebold (1804-1884) between May 1851 and January $1853^{[2]}$. Bilharz was able to distinguish the complications caused by infection with Distomum 
haematobium, as infiltration, bladder polyposis and sclerosis as well as kidney disease and could detect the parasite ova in urine and stools. Giesinger and Lautner directed his attention that this infection could be the cause of dysentery. Eventually, he discovered the parasite eggs in the diarrheic and dysenteric stool of cases. He also could recommend calomel (mercury chloride mineral with formula $\mathrm{Hg}_{2} \mathrm{Cl}_{2}$ ) to treat the infection $^{[3]}$. Bilharz described the detailed anatomical description of the parasite and the anatomical changes produced by it, and supplied excellent diagrams of a pair of the copulating flatworms and diagrams of the eggs. In these diagrams, he also depicted the eggs with lateral spines, which was later diagnosed as a different species by Patrick Manson (1844-1922). In 1903, Louis (Luigi) Westenra Sambon of the London School of Tropical Medicine named it in the year 1907, to honor his teacher Patrick Manson ${ }^{[13,14]}$.

Robert Thomas Leiber explored and reported on the life cycle of the identified worms in 1915 . He discovered its relationship with the snail intermediate hosts and could trace the different stages of the cycle in experimentally infected animals ${ }^{[14]}$.

In 1856, Meckel von Hemsbach named the parasite Bilharzia haematobium, to honor its discoverer, in his thesis entitled "The Geology of the Human Body". This work was published but had a limited circulation ${ }^{[15]}$. In 1858, Weinland, apparently not aware of this thesis, described the worm as Schistosoma haematobium. Nearly one hundred years later, in 1948 the International Commission on Zoological Nomenclature established the name Schistosoma accepted as the current name of the parasite ${ }^{[16,17]}$. However, both bilharziasis and schistosomiasis are used to denote the various diseases caused by the numerous species of the genus in man and animals ${ }^{[6]}$.

Bilharz shone in the sky of Cairo as a meteor. However, his early death made him easily forgotten. His memory came to light after about half a century during the First International Congress of Tropical Medicine, held in Cairo in 1928. The name of Bilharz and his great discoveries were mentioned and honored. Shortly, his complete biography was written, and his luminous personality was presented as an eminent German scientist ${ }^{[6]}$. Bilharz took his only European vacation in 1858, to return for the first and only time back to his homeland. He spent a five months holiday, during which he gave a lecture about his helminthic researches in Vienna. Later, he returned to Freiburg, Tubingen and his hometown Sigmaringen ${ }^{[3]}$.

Among his other famous discoveries, was the tiny cestode worm Hymenolepis nana in 1851 in the small intestine of an Egyptian boy in Cairo; and Heterophyes heterophyes in an autopsy of a native in Cairo ${ }^{[14]}$. In the following years, he was very interested in investigating the native fauna and made the first description of a
Nile fish, the Alestes macrolepidoteus (Nile perch), common names: Rie Safsafa-Kamboot (Arabic), Imberi (English) ${ }^{[2,18]}$. In 1856, Bilharz described the electrical organ of the Egyptian electric eel or "thunder fish" a common symbol seen in Egyptian hieroglyphics. Bilharz considered this study more important than his discovery of Schistosoma. Most of his work in the following decade focused on the study of ethnology, geography and ecology. However Bilharz did not publish this work, believing them to be of little significance ${ }^{[3,19]}$.

Early in the year 1862, Bilharz, agreed to accompany the Duke Ernst von Coburg on his hunting expedition in Somalia. Bilharz, however, remained in Massawa with the Duchess and there gave his whole medical attention to a German lady hopelessly stricken with typhoid fever or typhus. A few days after his return to Cairo, he fell dead as a victim to the fatal disease. In the literature, it was not very clear whether this disease was typhoid or typhus. Typhoid fever due to an outbreak in Massawa was reported to be the fatal disease that killed Bilharz ${ }^{[2,3,13]}$. Meanwhile, some other scientists reported that typhus was the serious disease that caused his death ${ }^{[5,11]}$. His funeral was attended by all his colleagues and family (Figure 7), and he was buried in the Catholic cemetery in Cairo (Figure 8), but not in the best of company. He shared the same plot with Hannes Eisele (1912-1967), a Nazi doctor who was found guilty and punished to death by a US military court. This punishment was changed to life in prison. Among his crimes to humans was the injection of experimental fluids into people (as guinea pigs) during the Second World War. He escaped from prison to Egypt and died there ${ }^{[2]}$.

The memory of Theodor Bilharz is honored by Egyptian scientists. The Department of Medical Parasitology, Kasr Al Ainy exhibits a statue of Bilharz (unknown artist) (Figure 9). Bilharz Research Institute in Cairo was established and named to honor him (Figure 10). Upon the hundredth anniversary of his death the Egyptian Post issued a stamp with his portrait in 1962 (Figure 11) ${ }^{[2]}$. Some of his hand drawings and diaries are kept and exhibited in the museum of Kasr Al Ainy "Medical School of Cairo University" (Figure 12, "9 figures").

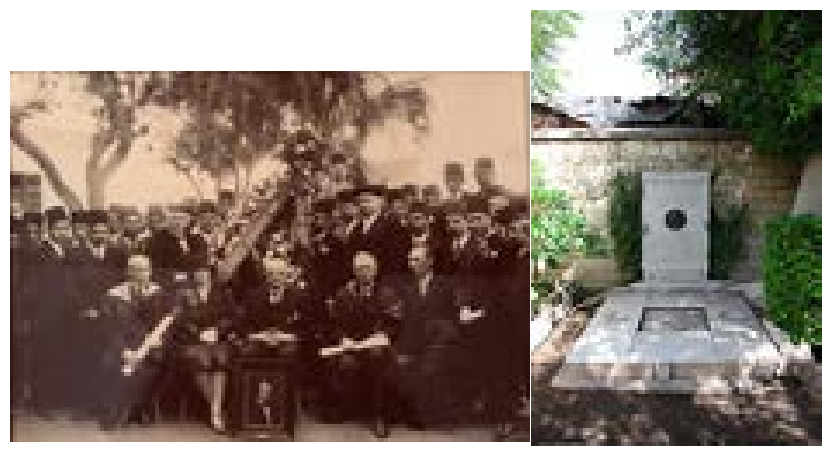

Figs. 7 and 8. The funeral of Theodor Bilharz, and his tomb in Cairo. 
In Sigmaringen, Germany, a school, a street and a pharmacy are named after him. Bilharz' younger brother, Alfons Bilharz, (1836-1925) who was a physician and philosopher, oversaw the Sigmaringen Hospitals from 1882 to $1907^{[2]}$.

Acknowledgment: The author expresses great appreciation to the supervisors of the museum of Kasr

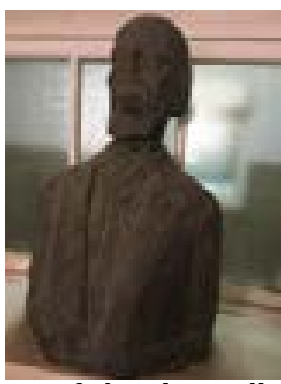

Fig. 9. Statue of Theodore Bilharz in the Department of Medical Parasitology, Faculty of Medicine, Cairo University (Kasr Al Ainy Medical School).
Al Ainy Medical School of Cairo University: Professor Hisham Minawy, Mrs. Eman Saber and Mrs. Eman Mosaad who allowed the taking of photos and the publishing of valuable documents in the museum.

Conflict of Interest: The author declares that there is no conflict of interest with any body.
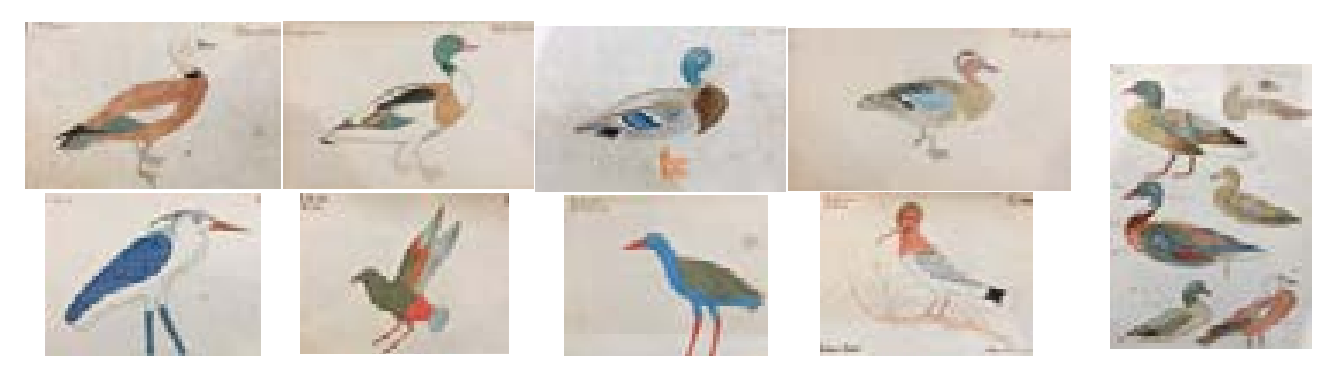

Fig. 12. Nine figures representing hand drawings of Theodor Bilharz of some birds in Egypt (museum of Kasr Al Ainy School of Medicine).

\section{REFERENCES}

1. Althoff A. Wissenschaftlicher Briefwechsel von und mit THEODOR BILHARZ. triltsch Druck und Verlag 1980.

2. www.whonamedit.com/doctor.cfm/2829.html

3. Eltawil KM, Plassmann M. Theodor Maximillian Bilharz (1825-1862): The discoverer of schistosomiasis. Inter J Parasitol Res 2011; 3: (1): 17-25.

4. Griffor E, Smorynski C. Logic's Lost Genius: The Life of Gerhard Gentzen (History of Mathematics, vol. 33). American Mathematical Society 2007; ISBN 978-0-8218-3550-0 (An English translation).

5. Knabe G. Im Kampfe gegen die 11. Plage. Das Leben des Theodor Bilharz. Steyler Verlag 1970.

6. El-Halawani AA. Theodor Bilharz, the history of bilharsiasis research with peculiar reference to Egypt. Proceedings of International Symposium on Bilharsisis, Memorial and Biography Lectures. Cairo, March, 1962; 69-71.

7. Kobelt, GL. Wikipedia 2006 ed: Available at: http:// www.bookrags.com/wiki/Georg_ Ludwig_Kobelt, Accessed June 16, 2008.

8. Halawani AA. J Egypt Med Assoc 1952; 35:89-93.

9. Schadelwaldt H. Dtsch Med Wochenschr 1955; 80:1053-1055.
10. El-Dib, N. Kasr Al Ainy, the story of a palace that became a medical school. KAMJ, 2015; 21(1): 1-7

11. The Behring-Bilharz Prize notes.

12. https://www.revolvy.com/page/Schistosomahaematobium

13. https://en.wikipedia.org/wiki/Louis_Westenra_ Sambon.

14. Beaver PC, Jung RC, Cupp EW. Clinical Parasitology. 8th ed. Lea-Febiger, 1986.

15. Meckel von Hemsbach JH. Biology of Schistosome complexes. Mikrogeologie, Berlin. Germany 1856; 27-31.

16. The 12th meeting of the International Commission on Zoological Nomenclature in 1948. Bull Zool Nomencl 1950; 4: 306-53. Whonamedit, Biographical dictionary, 2019.

17. Lotfy, WM. Human schistosomiasis in Egypt: Historical review, assessment of the current picture and prediction of the future trends. JMRI, 2009; 30 (1): 1-7.

18. Bishay HM, Khalil MT. Fresh water fishes of Egypt. EEAA, Department of Nature Protection. Publication of National Biodiversity Unit, No.9,1997.

19. Tan SY, Ahana A. Singapore Med J 2007;48:184-185. 